\title{
ANALISIS PENGARUH NON PERFORMING FINANCING DAN FINANCING TO DEPOSIT RATIO TERHADAP VOLUME PEMBIAYAAN PADA PERBANKAN SYARIAH DI INDONESIA DENGAN DANA PIHAK KETIGA SEBAGAI VARIABEL MEDIASI
}

\author{
Endriana W \\ Universitas Kuningan \\ (danidendri@yahoo.com)
}

\begin{abstract}
This study aims to analyze the effect of the NPF (non performing financing) and FDR (financing to deposit ratio) to the volume of financing of Islamic Banks in Indonesia with third-party funds as a mediating variable. The population in this study are all Islamic banks in Indonesia who registered at Bank Indonesia. Determination of the sample used by using purposive sampling, then obtain three Islamic banks were analyzed by mediation regression analysis which use multiple causal step method.

The results of this study indicate that the NPF has positive significant to the volume of financing of Islamic banks in Indonesia, FDR has no significant to the volume of financing of Islamic banks in Indonesia, NPF has positive significant to the third-party funds, FDR has no significant to the third-party funds, the third-party funds has positive significant to the volume of financing of Islamic banks in Indonesia, the third-party funds has significant effect in mediating NPF to the volume of financing of Islamic banks in Indonesia.
\end{abstract}

Keywords: A Volume of financing product, non performing financing (NPF), financing to deposit ratio (FDR), third-party funds

\section{PENDAHULUAN}

Alamsyah et al, 2009 (dalam Nugroho, 2009) menyatakan pentingnya kontribusi perbankan khususnya kredit dan pembiayaan bagi perekonomian Indonesia seperti pada kutipan berikut.

Banks are not only the major source of funding to small, medium as well as large corporations, they also determine the business cycle of the economy as a whole. For example, in Indonesia during 2001-2004, the flows of credit from the banking sector contributed on average about 77 percent of total financing from major financial institutions (banks, bond markets, and stock markets). As a result, the rise and fall of banks has strong correlation with economic booms and busts in Indonesia.

Penyaluran dana yang disalurkan kepada masyarakat dalam bentuk pembiayaan digunakan sebagai modal kerja yang dapat menggerakkan roda perekonomian masyarakat. Namun pada kenyataannya keputusan bank di dalam menyalurkan kredit memiliki banyak risiko. Berdasarkan Laporan Perkembangan Perbankan Syariah tahun 2012 yang terpublikasi dalam situs resmi Bank Indonesia, hasil penilaian profil risiko terhadap BUS (bank umum 
syariah) di Indonesia selama tahun 2012, menunjukkan bahwa persentase jumlah BUS yang memiliki profil risiko Moderate to High mencapai 9,1\%, sedangkan BUS lainnya memiliki profik risiko Moderate (90,9\%). Jumlah tersebut meningkat dibandingkan profil risiko BUS selama tahun 2011. Risiko yang secara signifikan mempengaruhi profil risiko bank syariah secara keseluruhan adalah risiko kredit. Risiko tersebut adalah kemungkinan terjadinya sebuah peristiwa yang tidak menguntungkan bagi bank. Oleh karena itu, pemberian kredit atau pembiayaan oleh bank harus dianalisis dengan teliti agar pembiayaan yang diberikan dapat dikembalikan sesuai dengan perjanjian yang telah disepakati.

Risiko kredit atau risiko pembiayaan yang mungkin dihadapi oleh bank syariah berkaitan dengan faktor internal maupun faktor eksternal. Faktor eksternal seperti debitur yang tidak mampu membayar pinjaman dan keadaan ekonomi suatu negara. Faktor internal yang menyebabkan kemungkinan risiko kredit yang dihadapi oleh bank semakin besar adalah tingkat kesehatan bank. (Galih, 2011)

Kinerja merupakan cerminan dari kemampuan perusahaan didalam mengelola dan mengalokasikan sumber dayanya. Kinerja perbankan syariah dapat dilihat dari laporan keuangan yang dibuat setiap periodenya. Pengukuran kinerja keuangan dalam penelitian ini menggunakan rasio keuangan NPF (non performing financing) dan FDR (financing to deposit ratio). Dipilihnya rasio NPF (non performing financing) dan FDR (financing to deposit ratio) sebagai proksi kenerja keuangan karena rasio NPF dan FDR paling menggambarkan tingkat kesehatan bank umum syariah. NPF (non performing financing) merupakan presentasi jumlah kredit bermasalah dengan kriteria kurang lancar, diragukan, dan macet terhadap total kredit yang dikeluarkan oleh bank (Taswan, 2005). FDR (financing to deposit ratio) merupakan rasio yang menggambarkan tingkat likuiditas bank.

Penelitian yang berkaitan dengan pengaruh LDR terhadap penyaluran kredit dilakukan oleh (Kurniawati, 2010) dalam (Yulhasnita, 2011), hasil penelitiannya menunjukkan bahwa LDR berpengaruh signifikan terhadap jumlah kredit yang diberikan pada bank umum nasional yang listing di BEI. Penelitian selanjutnya dilakukan oleh (Anindita, 2011), hasil penelitianya berbeda yaitu menunjukkan bahwa LDR tidak berpengaruh signifikan terhadap penyaluran kredit UMKM, dan oleh Giannini (2013) yang hasil penelitiannya menunjukkan bahwa FDR berpengaruh negatif terhadap pembiayaan mudharabah.

\section{KERANGKA TEORITIS DAN HIPOTESIS}

\section{A. Kerangka Teoritis}

Teori Kegunaan-Keputusan

(decision-usefulness theory) menyatakan bahwa kegunaan-keputusan informasi akuntansi mengandung komponenkomponen yang perlu dipertimbangkan oleh para penyaji informasi akuntansi agar cakupan yang ada dapat memenuhi kebutuhan para pengambil keputusan yang akan menggunakannya. (Pratiwi, 2010). Masyarakat perlu mengetahui apakah kinerja dan kondisi bank syariah dalam keadaan baik atau tidak. Informasi mengenai kinerja keuangan dapat didapatkan dari laporan keuangan yang diterbitkan oleh bank syariah yang bersangkutan. Hal tersebut menjadi informasi yang penting bagi para calon nasabah sebelum menyimpan dananya di bank syariah, kreditur membutuhkan informasi untuk mengetahui apakah 
kinerja dan kondisi bank syariah dalam keadaan baik atau tidak.

Informasi dalam laporan keuangan juga digunakan oleh manajemen di dalam pengambilan keputusan tentang pemberian dan penyaluran pembiayaan atau kredit kepada nasabah ataupun masyarakat yang membutuhkan dana. Dengan melakukan analisis laporan keuangan menggunakan rasio keuangan, yaitu NPF dan FDR, manajemen dapat menentukan apakah suatu kredit atau pembiayaan layak diberikan atau tidak. Hal tersebut dilakukan manajemen karena adanya risiko kredit yang kemungkinan dihadapi oleh bank di dalam memberikan pembiayaan.

\section{B. Hipotesis}

Penelitian yang dilakukan (Yuda dan Meiranto, 2010) menghasilkan bahwa NPL (Non Performing Loan) tidak berpengaruh signifikan terhadap jumlah kredit yang disalurkan. Menurut (Priatin dan Adnan, 2005) semakin ketat kebijakan kredit atau analisis pembiayaan yang dilakukan manajemen bank (semakin ditekan tingkat NPF) akibat rasio NPF sebelumnya tinggi, akan menyebabkan tingkat penyaluran pembiayaan menurun. Hal ini disebabkan karena bank akan melakukan proses pembiayaan dengan lebih berhati-hati untuk dapat menghindari risiko pembiayaan bermasalah. Semakin tinggi rasio NPF, menunjukkan kualitas pembiayaan bank syariah semakin buruk. Rasio NPF yang tinggi mengakibatkan kelancaran kegiatan usaha bank syariah menjadi terganggu, sehingga tingkat kesehatan bank pun menjadi menurun. Akibat tingginya NPF, perbankan harus menyediakan pencadangan yang lebih besar, sehingga pada akhirnya modal bank ikut terkikis. Padahal besaran modal sangat mempengaruhi besarnya ekspansi kredit atau pembiayaan. Akibatnya pula, bank akan semakin berhati- hati atau selektif dalam melakukan proses pembiayaan untuk menghindari risiko pembiayaan bermasalah. Hal ini dikarenakan adanya potensi pembiayaan yang dapat tidak tertagih.

\section{$\mathrm{H}_{1}$ : NPF berpengaruh negatif terhadap volume pembiayaan Bank Umum Syariah di Indonesia.}

Bank yang mempunyai FDR yang sangat tinggi, maka bank tersebut akan mempunyai risiko tidak tertagihnya pinjaman yang tinggi sehingga pada titik tertentu bank akan mengalami kerugian (Susilo, 2000) dalam (Anindita, 2011). Oleh karenanya Bank Indonesia dalam Peraturan Bank Indonesia tahun 2013 telah menetapkan standar untuk FDR yaitu berkisar antara $78 \%$ sampai dengan $92 \%$. Dengan demikian FDR diprediksi mempunyai pengaruh yang signifikan terhadap penyaluran pembiayaan atau kredit.

Penelitian yang berkaitan dengan pengaruh LDR terhadap penyaluran kredit dilakukan oleh Kurniawati (2010) dalam Yulhasnita (2011), hasil penelitiannya menunjukkan bahwa LDR berpengaruh negatif dan signifikan terhadap jumlah kredit yang diberikan pada bank umum nasional yang listing di Bursa Efek Indonesia. FDR merupakan faktor untuk mengukur tingkat kesehatan bank pada bagian likuiditas. FDR juga berkaitan dengan penyaluran pembiayaan karena dari kegiatan penyaluran pembiayaan atau penyaluran kredit bank dapat memenuhi kewajiban jangka pendeknya, membayar kembali semua deposan yang mengambil dana sewaktu-waktu, serta memenuhi kredit yang diajukan..

$\begin{array}{rlr}\mathrm{H}_{2}: & \text { FDR berpengaruh } \\ & \text { negatif terhadap volume } \\ & \text { pembiayaan } \quad \text { Bank } \\ & \text { Umum Syariah di } \\ & \text { Indonesia. }\end{array}$


(Mardiansyah, 2004) menemukan bahwa NPF memiliki pengaruh yang negatif dan signifikan terhadap dana pihak ketiga. Naiknya pembiayaan bermasalah akan memberikan disinsentif terhadap kemauan (willingness) masyarakat yang rasional untuk menabungkan dananya di bank syariah. Tingginya NPF akan menyebabkan deposan yang tadinya menyimpan dananya di bank syariah akan menarik kembali dana yang disimpannya karena khawatir bank syariah tidak dapat mengembalikan dananya akibat terjadi pembiayaan bermasalah tersebut.

$\begin{aligned} \mathrm{H}_{3}: & \text { NPF } \\ & \text { negatif terhadap dana } \\ & \text { pihak ketiga (DPK) } \\ & \text { Bank Umum Syariah di } \\ & \text { Indonesia. }\end{aligned}$

FDR merupakan perbandingan antara seluruh jumlah kredit yang diberikan bank dengan dana yang diterima bank (Dendawijaya, 2001). (Chaeruddin, 2003) menunjukkan bahwa manajemen kredit bank syariah akan mempengaruhi likuiditas bank itu sendiri dan akhirnya akan mempengaruhi penghimpunan dana dari pihak ketiga. Semakin tinggi rasio ini, maka semakin rendah pula kemampuan likuiditas bank tersebut, sehingga jika ada deposan menarik dananya kemungkinan suatu bank dalam kondisi bermasalah akan semakin besar. Hal ini akan turut mempengaruhi deposan dalam memilih dimana akan menghimpun dananya. Hipotesis keempat yang dirumuskan adalah:

\section{$\mathrm{H}_{4}$ : FDR berpengaruh negatif terhadap dana pihak ketiga (DPK) Bank Umum Syariah di Indonesia.}

Hasil penelitian (Anastasya dkk, 2013) menunjukkan bahwa DPK tidak berpengaruh terhadap pembiayaan berbasis bagi hasil. Sedangkan (Anggrahini, 2003) menemukan bahwa dana pihak ketiga (DPK) berpengaruh positif dan signifikan terhadap kredit perbankan. Kegiatan bank setelah menghimpun dana dari masyarakat luas adalah menyalurkan kembali dana tersebut kepada masyarakat yang membutuhkannya, dalam bentuk pinjaman atau pembiayaan. Jadi semakin tinggi tingkat DPK suatu bank syariah, maka akan semakin tinggi pula jumlah pembiayaan yang dilakukan oleh bank syariah tersebut.

\section{$\mathrm{H}_{5}$ : $\quad$ DPK berpengaruh positif terhadap volume pembiayaan Bank Umum Syariah di Indonesia}

Naiknya pembiayaan bermasalah akan memberikan disinsentif terhadap kemauan (willingness) masyarakat yang rasional untuk menabungkan dananya di bank syariah. Tingginya NPF akan menyebabkan deposan yang tadinya menyimpan dananya di bank syariah akan menarik kembali dana yang disimpannya karena khawatir bank syariah tidak dapat mengembalikan dananya akibat terjadi pembiayaan bermasalah tersebut. Sedangkan rasio FDR menunjukkan seberapa besar kemampuan bank dalam membayar kembali penarikan dana yang dilakukan deposan dengan mengandalkan kredit yang diberikan sebagai sumber likuiditasnya. Semakin tinggi rasio ini, maka semakin rendah pula kemampuan likuiditas bank tersebut, sehingga jika ada deposan menarik dananya kemungkinan suatu bank dalam kondisi bermasalah akan semakin besar. Hal ini akan turut mempengaruhi deposan dalam memilih dimana akan menghimpun dananya.

Kegiatan bank setelah menghimpun dana dari masyarakat luas adalah menyalurkan kembali dana 
tersebut kepada masyarakat yang membutuhkannya, dalam bentuk pinjaman atau pembiayaan. Jadi semakin tinggi tingkat DPK suatu bank syariah, maka akan semakin tinggi pula jumlah pembiayaan yang dilakukan oleh bank syariah tersebut. Berdasarkan hal tersebut, maka hipotesis keenam yang dirumuskan ada dua, yaitu:

\section{$\mathrm{H}_{6}$ : a. DPK memediasi pengaruh NPF terhadap volume pembiayaan \\ Bank Umum Syariah di Indonesia \\ b. DPK memediasi pengaruh FDR terhadap volume pembiayaan Bank Umum Syariah di Indonesia}

\section{METODOLOGI}

\section{A. Metode Penelitian}

Penelitian ini merupakan studi kuantitatif pada perbankan syariah di Indonesia menggunakan analisis data sekunder yang berasal dari laporan keuangan bank syariah di Indonesia. Penentuan sampel dalam penelitian ini menggunakan metode Purposive Sampling, dengan menggunakan data time lag atau selisih waktu sebanyak satu tri wulan dari keseluruhan populasi yang ada dipilih kembali berdasarkan kriteria yaitu: berstatus sebagai bank Islam komersial bukan merupakan Unit Usaha, serta menerbitkan laporan keuangan tri wulan periode 2008-2012.

\section{B. Teknik Analisis Data}

- Definisi Operasional dan Pengukuran Variabel

a. Dana Pihak Ketiga (DPK)

Dana Pihak Ketiga merupakan simpanan pihak ketiga bukan bank yang terdiri dari giro, tabungan, dan simpanan berjangka (deposito). Nilainya dapat dilihat pada posisi DPK bank syariah pada akhir periode yang dinyatakan dalam miliar rupiah (Yuda dan Meiranto, 2010).

b. Non performing financing (NPF) Merupakan rasio yang menggambarkan jumlah pembiayaan bermasalah terhadap total pembiayaan yang diberikan oleh bank (Maryanah, 2006 dalam Giannini, 2012). Rumusnya:

$\mathrm{NPF}=\frac{\text { Kredit Bermasalah }}{\text { Total Kredit }} \times 100 \%$

b. Financing to deposit ratio (FDR)

Financing to deposit ratio adalah rasio antara jumlah pembiayaan yang diberikan bank dengan dana pihak ketiga yang diterima oleh bank (Setiawan, 2012 dalam Giannini, 2012). Rumusnya adalah:

$$
\text { FDR }=\frac{\text { Jumlah pembiayaan }}{\text { Totaldana pihak ketiga }} \times 100 \%
$$

c. Volume Pembiayaan

Posisi besarnya volume pembiayaan atau total pembiayaan yang disalurkan oleh Bank Umum Syariah pada akhir periode.

\section{Tahap Analisis Data}

1. Uji Asumsi Klasik

Ada empat macam uji asumsi klasik yang dilakukan dalam pengujian hipotesis model regresi linear berganda untuk penelitian ini, yaitu uji normalitas, multikolonearitas, heteroskedastisitas, dan autokorelasi.

\section{Pengujian Hipotesis}

a. Pengujian Hipotesis Kesatu dan Kedua

Persamaan regresi berganda untuk hipotesis kesatu dan 
kedua adalah sebagai berikut:

$\mathrm{Y}=\mathrm{a}+\mathrm{b}_{1} \mathrm{X}_{1}+\mathrm{b}_{2} \mathrm{X}_{2}+\varepsilon$

keterangan :

$\mathrm{Y}=$ Pembiayaan Bank

Umum Syariah

$\mathrm{X}_{1} \quad=$ Non performing financing (NPF) Bank Umum Syariah

$\mathrm{X}=$ Financing to deposit

ratio (FDR) Bank Umum Syariah

$b_{2} \quad=$ Koefisien FDR

$b_{1} \quad=$ Koefisien NPF

$\mathrm{a} \quad=$ Konstanta (intercept)

$\varepsilon \quad=$ residual

b. Pengujian Hipotesis Ketiga dan Keempat

Persamaan regresi berganda untuk hipotesis ketiga dan keempat adalah sebagai berikut: $\mathrm{M}=\mathrm{a}+\mathrm{b}_{4} \mathrm{X}_{1}+\mathrm{b}_{5} \mathrm{X}_{2}+$ $\varepsilon$

c. Pengujian Hipotesis Kelima

Persamaan regresi berganda untuk hipotesis kelima adalah sebagai berikut:

$\mathrm{Y}=\mathrm{a}+\mathrm{c}_{1} \mathrm{X}_{1}+\mathrm{c}_{2} \mathrm{X}_{2}+\mathrm{b}_{3} \mathrm{M}+$ $\varepsilon$

d. Pengujian Hipotesis Keenam

Hipotesis keenam diuji dengan menggunakan analisis regresi berganda dengan metode kausal step berganda. Analisis regresi variabel mediasi dengan metode kausal step dikembangkan oleh (Baron dan Kenny, 1986) yang dikutip dari (Suliyanto, 2011). Untuk memahami pengujian mediasi menggunakan metode ini maka digunakan tiga persamaan regresi sebagai berikut:

$\begin{array}{ll}\text { Persamaan I } & : Y \\ =\alpha_{1}+c X & \\ \text { Persamaan II } & : \mathcal{M}= \\ & \alpha_{2}+a X \\ \text { Persamaan III } & : Y= \\ \alpha_{3}+c X+b M & \end{array}$

HASIL PENELITIAN dan PEMBAHASAN

A. Analisis Data dan Pembahasan

1. Pengujian Hipotesis Pertama dan Hipotesis Kedua

- Hasil uji asumsi klasik untuk hipotesis pertama dan kedua adalah sebagai berikut :

Hasil uji Kolmogorov-Smirnov Z untuk unstandardized residual variable sebesar 0,268 lebih besar dari nilai alpha $(\alpha)$ yaitu 0,05 , sehingga dapat dinyatakan bahwa nilai residual regresi berdistribusi normal. Sedangkan, hasil analisis regresi diperoleh nilai signifikansi masing-masing variabel yang diuji memiliki nilai lebih besar dari nilai alpha $(\alpha)=0,05$ sehingga dapat dikatakan bahwa tidak terdapat gejala heteroskedastisitas dalam model regresi. Nilai VIF masing-masing variabel yang diuji memiliki nilai lebih kecil dari 10, sehingga dapat dinyatakan tidak ada gejala multikolinearitas dalam model regresi. Sedangkan hasil uji dari tabel Durbin Watson menunjukkan nilai DW sebesar 1,720. Sehingga nilai DW berada pada dU sampai dengan 4-dU. Dengan demikian, dapat ditarik kesimpulan bahwa tidak ada autokorelasi pada model ini.

- Berdasarkan hasil pengujian persamaan regresi untuk hipotesis pertama dan kedua adalah sebagai berikut: $\mathrm{Y}=6,436+0,969 \mathrm{NPF}+$ 3,116 FDR

Pengujian signifikansi pengaruh variabel independent terhadap variabel dependent secara parsial menggunakan uji t. Berdasarkan output regresi pada lampiran 3 diperoleh nilai $t$ hitung variabel NPF 3,059, lebih besar dari nilai $\mathrm{t}$ tabel sebesar 1,675. Hasil pengujian variabel NPF nilai sig. $t$ hitung sebesar 0,004 lebih kecil dari nilai alpha $(\alpha)=0,05$.Dengan $t$ hitung mempunyai arah koefisien positif, maka dapat disimpulkan bahwa variabel NPF 
berpengaruh positif terhadap volume pembiayaan bank umum syariah. Dengan demikian, maka hipotesis pertama ditolak.

Berdasarkan output regresi pada lampiran 3 diperoleh nilai $t$ hitung variabel FDR 2,004 lebih besar dari nilai $t$ tabel sebesar 1,675. Hasil pengujian variabel FDR nilai sig. $t$ hitung sebesar 0,050 sama dengan nilai alpha $(\alpha)=0,05$. Berdasarkan hasil tersebut, maka dapat disimpulkan bahwa variabel FDR tidak berpengaruh terhadap volume pembiayaan bank umum syariah. Dengan demikian, maka hipotesis kedua ditolak.

\section{Pengujian Hipotesis Ketiga dan} Hipotesis Keempat

- Hasil uji asumsi klasik untuk nilai asymp.sig. (2-tailed) dari uji Kolmogorov Smirnov Z untuk unstandardized residual variable sebesar 0,355 lebih besar dari nilai alpha $(\alpha)$ yaitu 0,05 , sehingga dapat dinyatakan bahwa nilai residual regresi berdistribusi normal. Berdasarkan hasil analisis regresi diperoleh nilai signifikansi masing-masing variabel yang diuji memiliki nilai lebih besar dari nilai alpha $(\alpha)=0,05$. Berdasarkan data tersebut dapat dikatakan bahwa tidak terdapat gejala heteroskedastisitas dalam model regresi. Hasil menunjukan bahwa tidak ada gejala multikolinearitas dalam model regresi karena nilai VIF masing-masing variabel yang diuji memiliki nilai lebih kecil dari 10 . Sedangkan, hasil perhitungan menunjukkan nilai DW sebesar 1,757. Sehingga nilai DW berada pada dU sampai dengan 4-dU. Dengan demikian, dapat ditarik kesimpulan bahwa tidak ada autokorelasi pada model ini.

- Berdasarkan hasil pengujian persamaan regresi untuk hipotesis ketiga dan keempat adalah sebagai berikut: $\mathrm{M}=$ 7,359 + 0,925 NPF + 2,681 FDR
Pengujian signifikansi pengaruh variabel independent terhadap variabel dependent secara parsial menggunakan uji t. Berdasarkan output regresi pada lampiran 4 diperoleh nilai $t$ hitung variabel NPF 2,926 dan nilai $t$ hitung variabel FDR 1,727 lebih besar dari nilai $\mathrm{t}$ tabel sebesar 1,675. Hasil pengujian variabel NPF nilai sig. $t$ hitung sebesar 0,005 lebih kecil dari nilai alpha $(\alpha)=0,05$ dan untuk variabel FDR nilai sig. $t$ hitung sebesar 0,090 lebih besar dari nilai alpha $(\alpha)=0,05$. Dengan $t_{\text {hitung }}$ mempunyai arah koefisien positif, maka dapat disimpulkan bahwa variabel NPF berpengaruh positif terhadap dana pihak ketiga (DPK). Dengan demikian, maka hipotesis ketiga yang menyatakan bahwa NPF berpengaruh negatif terhadap DPK ditolak.

Berdasarkan output regresi diperoleh nilai $\mathrm{t}$ hitung variabel FDR 1,727 lebih besar dari nilai $t$ tabel sebesar 1,675. Hasil pengujian variabel FDR nilai sig. $\mathrm{t}_{\text {hitung }}$ sebesar 0,090 lebih besar dari nilai alpha $(\alpha)=0,05$. Berdasarkan hasil tersebut, maka dapat disimpulkan bahwa variabel FDR tidak berpengaruh terhadap DPK (dana pihak ketiga) bank umum syariah. Dengan demikian, maka hipotesis keempat ditolak.

\section{Pengujian Hipotesis Kelima dan Hipotesis Keenam}

- Hasil uji asumsi klasik untuk hipotesis kelima dan keenam adalah sebagai berikut :

Nilai asymp.sig. (2-tailed) dari uji Kolmogorov-Smirnov $\mathrm{Z}$ untuk unstandardized residual variable sebesar 0,846 lebih besar dari nilai alpha $(\alpha)$ yaitu 0,05 , sehingga dapat dinyatakan bahwa nilai residual regresi berdistribusi normal. Tidak terdapat gejala heteroskedastisitas dalam model regresi, ditunjukkan dengan hasil analisis regresi diperoleh nilai signifikansi masing-masing variabel yang diuji memiliki nilai lebih besar 
dari nilai alpha $(\alpha)=0,05$. Diketahui nilai VIF masing-masing variabel yang diuji memiliki nilai lebih kecil dari 10 , sehingga dapat dinyatakan tidak ada gejala multikolinearitas dalam model regresi. Untuk pengujian autokorelasi diperoleh hasil perhitungan menunjukkan nilai DW sebesar 1,743. Sehingga nilai DW berada pada dU sampai dengan 4-dU. Dengan demikian, dapat ditarik kesimpulan bahwa tidak ada autokorelasi pada model ini.

- Berdasarkan hasil uji regresi, dapat dibuat persamaan regresi sebagai berikut: $\mathrm{Y}=-0,914+$ $0,045 \mathrm{NPF}+0,438 \mathrm{FDR}+0,999$ DPK.

Pengujian signifikansi pengaruh variabel independent terhadap variabel dependent secara parsial menggunakan uji t. Berdasarkan output regresi pada lampiran 5 diperoleh nilai $t$ hitung variableDPK adalah 95,254 lebih besar dari nilai $t$ tabel sebesar 1,675. Hasil pengujian variabel DPK nilai sig. $t_{\text {hitung }}$ sebesar 0,000 lebih kecil dari nilai alpha $(\alpha)=0,05$. Berdasarkan hasil regresi tersebut, maka dapat disimpulkan bahwa variabel DPK berpengaruh positif terhadap volume pembiayaan bank umum syariah. Dengan demikian, maka hipotesis kelima diterima.

Hipotesis keenam dilakukan untuk mengetahui apakah DPK memediasi pengaruh NPF dan FDR terhadap volume pembiayaan pada bank umum syariah di Indonesia. Pengujian dilakukan dengan menggunakan analisis regresi variabel mediasi dengan metode kausal step. Pengujian signifikansi pengaruh variabel independen dan mediasi terhadap variabel dependen secara parsial menggunakan uji $t$, dengan hasil pengujian untuk masingmasing variabel sebagai berikut:

Variabel NPF

Berdasarkan output regresi diperoleh nilai $\mathrm{t}$ hitung variabel NPF sebesar 1,729 lebih besar dari nilai $\mathrm{t}_{\text {tabel }}$ sebesar 1,675. Output regresi juga menunjukkan bahwa nilai sig. $\mathrm{t}$ hitung sebesar 0,090 lebih besar dari nilai alpha $(\alpha)=0,05$, maka dapat disimpulkan bahwa variabel NPF tidak berpengaruh terhadap volume pembiayaan bank umum syariah.

(2) Variabel FDR

Berdasarkan output regresi diperoleh nilai $\mathrm{t}$ hitung variabel FDR sebesar 3,627 lebih besar dari nilai t tabel sebesar 1,675. Output regresi juga menunjukkan bahwa nilai sig. $\mathrm{t}$ hitung sebesar 0,000 lebih kecil dari nilai alpha $(\alpha)=0,05$. Dengan $t$ hitung mempunyai arah koefisien positif, maka dapat disimpulkan bahwa variabel FDR berpengaruh positif terhadap volume pembiayaan bank umum syariah.

(3) Variabel DPK

Berdasarkan output regresi diperoleh nilai $\mathrm{t}$ hitung variabel DPK adalah 95,254 lebih besar dari nilai $t$ tabel sebesar 1,675. Output regresi juga menunjukkan bahwa nilai sig. $t$ hitung sebesar 0,000 lebih kecil dari nilai alpha $(\alpha)=0,05$. Dengan $t$ hitung mempunyai arah koefisien positif, maka dapat disimpulkan bahwa variabel DPK berpengaruh positif terhadap volume pembiayaan bank umum syariah.

Berdasarkan hasil analisis di atas diketahui bahwa variabel bebas NPF berpengaruh terhadap variabel mediasi (DPK). Variabel mediasi (DPK) berpengaruh terhadap variabel tergantung (volume pembiayaan). Variabel DPK dinyatakan sebagai variabel mediasi sempurna, karena setelah memasukkan variabel DPK dalam persamaan regresi, pengaruh variabel independen NPF terhadap variabel dependen (volume pembiayaan) yang tadinya signifikan menjadi tidak signifikan.

Berdasarkan hasil analisis di atas juga dapat diketahui bahwa variabel 
independen FDR tidak berpengaruh terhadap variabel mediasi (DPK), sehingga variabel DPK tidak memediasi pengaruh variabel FDR terhadap variabel volume pembiayaan.

\section{B. Pembahasan Hasil Penelitian}

a. Hipotesis Kesatu

Hasil pengujian dengan analisis regresi menunjukan bahwa NPF berpengaruh positif terhadap volume pembiayaan bank umum syariah di Indonesia. Hasil pengujian juga bertentangan dengan hipotesis yang telah dirumuskan dalam penelitian ini, yaitu yang menyatakan bahwa NPF berpengaruh negatif terhadap volume pembiayaan bank umum syariah. Hipotesis pertama ditolak karena adanya perbedaan karakteristik NPF Bank Syariah Mega Indonesia yang berbeda dibandingkan dengan Bank Syariah Mandiri dan Bank Muamalat Indonesia. Bank Syariah Mega Indonesia memiliki nilai NPF yang cenderung meningkat selama tahun 2008 hingga tahun 2012, sehingga hal tersebut apabila di regresikan bersama dengan bank yang lainnya, berpengaruh terhadap hipotesis yang dihasilkan.

Hasil analisis regresi tanpa menggunakan data dari Bank Syariah Mega Indonesia menunjukkan bahwa NPF berpengaruh negatif terhadap volume pembiayaan, sehingga peneliti menyimpulkan bahwa hipotesis pertama ditolak karena adanya perbedaan karakteristik data NPF milik Bank Syariah Mega Indonesia.

b. Hipotesis Kedua
Hasil pengujian dengan analisis regresi menunjukan bahwa FDR tidak berpengaruh terhadap volume pembiayaan bank umum syariah di Indonesia. Hal ini berarti bahwa peningkatan dalam nilai FDR tidak berpengaruh terhadap volume pembiayaan bank umum syariah. Hasil tersebut sejalan dengan penelitian yang dilakukan oleh Yulhasnita (2011), namun bertentangan dengan hipotesis yang disimpulkan dalam penelitian ini.

FDR tidak berpengaruh terhadap volume pembiayaan pada bank umum syariah, alasannya adalah karena ratarata nilai FDR dari bank umum syariah dalam penelitian ini sudah berada dalam batas ideal ketentuan Bank Indonesia tahun 2013, yaitu berkisar antara $78 \%$ - 92\%, dan juga karena sebagian besar nasabah bank syariah merupakan nasabah yang loyal, sehingga bukan merupakan pertimbangan utama manajemen bank syariah di dalam mengambil keputusan mengenai penyaluran pembiayaan.

c. Hipotesis Ketiga

Hasil pengujian menunjukan bahwa NPF berpengaruh positif terhadap DPK (dana pihak ketiga). Hasil ini bertentangan dengan hipotesis yang telah dirumuskan sebelumnya, yaitu yang menyatakan bahwa NPF berpengaruh negatif terhadap DPK. Hipotesis ketiga ditolak karena karena adanya perbedaan karakteristik NPF Bank Syariah Mega Indonesia berbeda dibandingkan dengan Bank Syariah Mandiri dan Bank 
Muamalat Indonesia. Bank Syariah Mega Indonesia memiliki nilai NPF yang cenderung meningkat selama tahun 2008 hingga tahun 2012, sehingga hal tersebut apabila di regresikan bersama dengan bank yang lainnya, berpengaruh terhadap hipotesis yang dihasilkan.

Berdasarkan hasil analisis regresi tanpa menggunakan data Bank Syariah Mega Indonesia, menunjukkan bahwa NPF berpengaruh negatif terhadap dana pihak ketiga (DPK), sehingga peneliti menyimpulkan bahwa hipotesis ketiga ditolak karena adanya karakteristik data NPF milik Bank Syariah Mega Indonesia yang berbeda, yaitu cenderung meningkat.

d. Hipotesis Keempat

Hasil analisis regresi menunjukkan bahwa FDR tidak berpengaruh terhadap DPK (dana pihak ketiga). Hasil tersebut bertentangan dengan hipotesis yang sebelumnya telah dirumuskan dalam penelitian ini, yang menyatakan bahwa FDR berpengaruh negatif terhadap DPK. Diduga hal tersebut dapat terjadi karena sebagian besar masyarakat di dalam memilih bank, tidak melihat informasi tentang laporan keuangan bank tersebut dan juga karena alasan masyarakat dalam memilih bank umum syariah sebagai tempat menyimpan dananya adalah karena unsur agama.

Dengan menyimpan dananya di bank syariah, hal tersebut tidak bertentangan dengan syariat Islam yang mengharamkan sistem riba atau bunga. Menurut Karim (dalam
Republika tahun 2011), pasar perbankan syariah dibagi menjadi tiga segmen besar. Pertama, pasar yang loyal terhadap perbankan syariah (loyalis syariah). Kedua, pasar mengambang, yaitu yang dapat menerima kedua sistem perbankan konvensional dan perbankan syariah (floating mass). Ketiga, pasar yang loyal terhadap perbankan konvensional (loyalis konvensional). Tidak semua nasabah melihat informasi laporan keuangan suatu bank, sehingga masyarakat dalam memilih bank yang akan menjadi tempat menyimpan danaya tidak selalu memperhitungkan nilai FDR (Andriyanti, 2010).

e. Hipotesis Kelima

Hasil pengujian menunjukkan bahwa DPK (dana pihak ketiga) berpengaruh positif terhadap volume pembiayaan bank umum syariah di Indonesia. Hasil analisis ini sesuai dengan hipotesis yang telah dirumuskan sebelumnya. Penelitian yang telah dilakukan sebelumnya, yaitu oleh (Yuda dan Meiranto, 2010) dan (Anggrahini, 2003) juga menunjukkan hasil yang sama.

Dana pihak ketiga (DPK), adalah pangsa pasar dana pihak ketiga yang dihimpun oleh masing-masing bank secara individu. Semakin tinggi rasio ini, maka semakin baik tingkat kepercayaan masyarakat terhadap bank yang bersangkutan. Kegiatan bank setelah menghimpun dana dari masyarakat luas adalah menyalurkan kembali dana 
tersebut kepada masyarakat yang membutuhkannya, dalam bentuk pinjaman atau pembiayaan. Jadi semakin tinggi tingkat DPK suatu bank syariah, maka akan semakin tinggi pula jumlah pembiayaan yang dilakukan oleh bank syariah tersebut.

f. Hipotesis Keenam

Hasil pengujian hipotesis keenam dengan menggunakan analisis regresi variabel mediasi dengan metode kausal step menghasilkan bahwa variabel DPK (dana pihak ketiga) memediasi hubungan antara variabel NPF dengan variabel volume pembiayaan. Hal tersebut sesuai dengan hipotesis yang telah dirumuskan pada penelitian ini dan juga berarti bahwa keberadaan variabel dana pihak ketiga (DPK) merupakan variabel mediasi yang berfungsi memediasi hubungan antara variabel independen, yaitu NPF dengan variabel dependen, yaitu variabel volume pembiayaan.

DPK merupakan sumber dana bank yang berasal dari masyarakat sebagai nasabah dalam bentuk simpanan, giro, tabungan dan deposito. Bank sebagai suatu badan usaha tetap bertujuan untuk meningkatkan laba melalui setiap kegiatan operasionalnya, termasuk dalam fungsinya sebagai financial intermediary, yaitu menghimpun dana pihak ketiga (DPK) dan menyalurkannya kembali dalam bentuk kredit atau pembiayaan kepada pihak yang membutuhkan dana. Penyaluran kredit merupakan fungsi utama dari bank dan merupakan sumber pendapatan yang utama pada umumnya. Berdasarkan UU No. 10 Tahun 1998 tentang perbankan, dapat dikatakan bahwa besarnya penyaluran kredit perbankan bergantung pada besarnya jumlah dana pihak ketiga yang dapat dihimpun oleh bank (Harmanta dan Ekananda, 2005).

Hasil analisis regresi variabel mediasi dengan metode kausal step menunjukkan bahwa variabel DPK tidak memediasi pengaruh FDR terhadap volume pembiayaan bank umum syariah di Indonesia. Hal tersebut terjadi karena sebagian masyarakat di Indonesia dalam memilih bank untuk menyimpan dananya, tidak melihat dan kurang memperhatikan tentang laporan keuangan bank syariah. Selain itu, alasan dari sebagian masyarakat dalam memilih bank umum syariah sebagai tempat menyimpan dananya adalah karena unsur agama. (Andriyanti, 2010)

\section{SIMPULAN dan IMPLIKASI}

\section{A. Simpulan}

Berdasarkan hasil penelitian dan pembahasan, dapat disimpulkan bahwa NPF (non performing financing) berpengaruh positif terhadap volume pembiayaan pada bank umum syariah di Indonesia. Kemudian, FDR (financing to deposit ratio) tidak berpengaruh terhadap volume pembiayaan pada bank umum syariah di Indonesia. NPF (non performing financing) berpengaruh positif terhadap DPK (dana pihak ketiga), FDR (financing to deposit ratio) tidak berpengaruh terhadap DPK (dana pihak ketiga). DPK (dana pihak ketiga) berpengaruh positif terhadap volume pembiayaan pada bank umum syariah di Indonesia. Sedangkan, DPK 
memediasi sempurna pengaruh NPF (non performing financing) terhadap volume pembiayaan bank umum syariah di Indonesia. Serta, DPK tidak memediasi pengaruh FDR (financing to deposit ratio) terhadap volume pembiayaan bank umum syariah di Indonesia.

\section{B. Implikasi}

Hasil penelitian ini dapat memberikan manfaat bagi bank syariah sendiri untuk dapat mempertimbangkan penetapan kebijakan perusahaan serta peningkatan kinerja operasional dalam rangka meningkatkan kinerja keuangan perusahaan terutama terkait dengan variabel-variabel yang diteliti serta pengaruhnya bagi bank syariah.

\section{DAFTAR PUSTAKA}

Ahmad, Ziauddin. 1983. Islamic Banking: State Of The Art. International Centre for Research in Islamic Economics. King Abdul Aziz University. Jeddah.

Ahmad, Hayati Nor., Shahrul Ahmad. 2003. Key Factors Influencing Credit Risk of Islamic Bank: A Malaysian Case. Faculty of Banking and Finance. University Utara Malaysia.

Alamsyah, H., D. Zulverdi, I. Gunadi, R.Z. Idris dan B. Pramono. 2005. Banking

Disintermediation and Its Implication for Monetary Policy: The Case of Indonesia. Buletin Ekonomi Moneter dan Perbankan, Vol. 7 (4).

Andriyanti, Ani.,Wasilah. 2010. FaktorFaktor yang Mempengaruhi Jumlah Penghimpunan Dana Pihak Ketiga (Deposito Mudharabah 1 Bulan) Bank Muamalat Indonesia. Jurnal SNA XIII Purwokerto.
Anindita, Irma. 2011. Analisis Pengaruh Tingkat Suku Bunga, CAR, NPL dan LDR Terhadap Penyaluran kredit UMKM (Studi pada Bank Umum Swasta Nasional Periode 2003-2010). Universitas Diponegoro Semarang.

Antonio, M.S. 2000. Bank Syariah Suatu Pengenalan Umum. Tazkia Institute, Jakarta.

Arifin, Zainul. 2006. Dasar-dasar Manajemen Bank Syariah. Penerbit Alvabet. Jakarta.

Arisandi, Desi. 2007. Analisis Faktor Penawaran Kredit Pada Bank Umum di Indonesia. Jurnal Fakultas Ekonomi Universitas Gunadarma.

Budiawan. 2008. Analisis Faktor Faktor yang Mempengaruhi Penyaluran Kredit pada Bank Perkreditan Rakyat (Studi Kasus pada BPR di Wilayah Kerja BI Banjarmasin). Universitas Diponegoro Semarang.

Bringham, E.F dan Houston. 2006. Dasar-Dasar Manajemen Keuangan Edisi 10. Salemba Empat. Jakarta.

Chaeruddin, Syah. 2003. Manajemen Kredit Syariah Bank Muamalat. Kajian Ekonomi dan Keuangan, Vol. 7 (3).

Dendawijaya, Lukman. 2001. Manajemen Perbankan. Penerbit Ghalia Indonesia. Jakarta.

Ebrahim, M.S. and K.J. Tan. 2001. Islamic Banking in Brunei Darussalam. International Journal of Social Economics, 28 (4): 314-337.

Febrianto, Dwi. 2013. Analisis Pengaruh Dana Pihak Ketiga, LDR, NPL, CAR, ROA, Dan BOPO Terhadap Jumlah Penyaluran Kredit. Universitas Diponegoro Semarang. 
Galih, Tito. 2011. Pengaruh Pihak Ketiga, CAR, NPL, dan LDR Terhadap Jumlah Penyaluran Kredit pada Bank di Indonesia. Universitas Diponegoro Semarang.

Giannini, N.G. 2013. Faktor yang Mempengaruhi Pembiayaan Mudharabah pada Bank Umum Syariah di Indonesia. Accounting Analysis Journal, 1 (3).

Ghozali, Imam. 2005. Aplikasi Analisis Multivariate dengan Program

SPSS. Badan Penerbit

Universitas Diponegoro

Semarang.

Haque, Ahasanul, Jamil Osman. 2009. Factors Influences Selection of Islamic Banking: A Study on Malaysian Customer Preferences. American Journal of Applied Sciences, 6 (5): 922928.

Harmanta dan Mahyus Ekananda. 2005. Disintermediasi Fungsi Perbankan di Indonesia Pasca Krisis 1997 : Faktor Permintaan atau Penawaran Kredit, Sebuah Pendekatan dengan Model Disequilibrium. Buletin Ekonomi Moneter dan Perbankan.

Hutabarat, Sakti. 2010. Faktor-Faktor yang Mempengaruhi Keputusan Masyarakat Menjadi Nasabah Bank Syariah di Pekanbaru. Univeritas Riau.

Karim, Adiwarman. 2006. Bank Islam Analisis Fiqih dan Keuangan. Raja Grafindo Persada. Jakarta.

Kasri, Rahmatina, and Salina Kassim. 2009. Empirical Determinants of Saving in the Islamic Banks: Evidence from Indonesia. The Journal of King Abdulaziz University, 22 (2): 181-201.
Khatimah, Husnul. 2009. Analisis Faktor-Faktor yang Mempengaruhi Penyaluran Dana Perbankan Syariah di Indonesia Sebelum dan Sesudah Kebijakan Akselerasi Perbankan Syariah Tahun 2007/2008. Jurnal Fakultas Ekonomi Unisma.

Kuncoro, Mudrajad. 2003. Metode Riset untuk Bisnis dan Ekonomi. Erlangga. Jakarta.

Manurung, Mandala., Prathama Rahardja. 2004. Uang, Perbankan, dan Ekonomi Moneter (Kajian Kontekstual Indonesia). Penerbit FE UI. Jakarta.

Mardiansyah, Akhmad. 2004. Analisis Faktor-Faktor Penentu Penghimpunan dan Penyaluran Dana Perbankan Syariah Beserta Peramalannya. Institut Pertanian Bogor.

Muhamad, Firdaus. 2004. Ekonometrika Suatu Pendekatan Aplikatif. Bumi Aksara. Jakarta.

Nikensari, Sri Indah., Dian Sugiarti dan Tuty Sariwulan. 2012. Pembiayaan Mudharabah dan Kaitannya dengan NPF dan Bagi Hasil. Jurnal Econo Sains, Vol X (2).

Nugroho, Ris Yuwono. 2009. Analisis Faktor-Faktor Penentu Pembiayaan Perbankan Syariah Di Indonesia: Aplikasi Model Vector Error Correction. Institut Pertanian Bogor

Nurjaya, Endang. 2011. Analisis Pengaruh Inflasi, SBIS, NPF, dan DPK Terhadap Pembiayaan Murabahah Pada Bank Syariah di Indonesia. Universitas Islam Negeri Syarif Hidayatullah Jakarta.

Peraturan Bank Indonesia Nomor 15/2/PBI/2013 tanggal 20 Mei 
2013 Tentang Penetapan Status dan Tindak Lanjut Pengawasan Bank Umum Konvensional. http://www.bi.go.id/web/id/Perat uran/Perbankan/PBI_15_2_PBI 2013.htm?mweb=false, $\quad 09$ Desember 2013.

Pradana, Yoga., Djoko Sampurno. 2013. Analisis Pengaruh LDR, CAR, ROA, dan Faktor Eksternal Perbankan Terhadap Volume KPR pada Bank Persero Periode 2008-2012. ISSN Volume 2 (3).

Pratama, Billy. 2010. Analisis FaktorFaktor yang Mempengaruhi Kebijakan Penyaluran Kredit Perbankan (Studi pada Bank Umum di Indonesia Periode Tahun 2005-2009). Universitas Diponegoro Semarang.

Pratiwi, Amelia Ika. 2010. Decision Usefulness: Berdasarkan Teori Keputusan dan Teori Investasi. Jurnal Ilmiah Bisnis dan Ekonomi Asia Volume 5 (1). http://www.scribd.com/doc/8222 3702/Decision-Usefulness-

Berdasarkan-Teori-KeputusanDan-Teori-Investasi ， 09 Desember 2013.

Priatin, Akhyar Adnan. 2005. Analisis Hubungan Simpanan, Modal Sendiri, NPL, Prosentase Bagi Hasil dan Mark Up Keuntungan Terhadap Pembiayaan Pada Perbankan Syariah Studi Kasus Bank Muamalat Indonesia (BMI). Edisi Khusus on Finance. Sinergi. Universitas Islam Indonesia.

Republika. Segmentasi Pasar Perbankan Syariah.

http://permodalanbmt.com/bmtc entre/? $p=816$, 09 Desember 2013.

Soedarto, Mochamad. 2004. Analisis Faktor - Faktor yang
Mempengaruhi Penyaluran Kredit pada Bank Perkreditan Rakyat (Studi Kasus pada BPR di Wilayah Kerja BI Semarang). Universitas Diponegoro Semarang.

Sri Anastasya, dkk. 2013. The Influence of Third Party Funds, CAR, $N P F$, and ROA Against The Financing of A General ShariaBased Bank in Indonesia. International Conference on Business, Economic, and Accounting. Bangkok, Thailand.

Suhardjono. 2003. Manajemen Perkreditan. Penerbit UPPAMPYKPN. Jakarta.

Suliyanto. 2011. Ekonometrika Terapan : Teori dan Aplikasi dengan SPSS. Penerbit ANDI. Yogyakarta.

Suruji, Andi, dkk. 1998. Laporan Akhir Tahun Bidang Ekonomi (Krisis Ekonomi 1998, Tragedi tak Terlupakan).

http://www.seasite.niu.edu/indon esian/Reformasi/Krisis_ekonomi .htm, 09 Desember 2013.

Ulum, Ihyaul. 2007. Pengaruh Intellectual Capital Terhadap Kinerja Keuangan Perusahaan Perbankan di Indonesia. Universitas Diponegoro Semarang

Undang-Undang Nomor 7 Tahun 1992 Tentang Perbankan.

Undang-Undang Nomor 10 Tahun 1998 Tentang Perbankan.

Undang-Undang Nomor 21 Tahun 2008 Tentang Perbankan Syariah.

Wiyono, Slamet. 2005. Cara Mudah Memahami Akuntansi Perbankan Syariah Berdasarkan PSAK dan PAPSI. Penerbit Gramedia Widiasarana Indonesia. Jakarta.

www.bi.go.id. Indikator Perbankan Nasional 
www.bi.go.id. Statistik Perbankan Indonesia

www.bi.go.id. Statistik Ekonomi Moneter Indonesia

www.bsmi.co.id. Profil Bank Syariah Mega Indonesia

www.infobanknews.com

Yaya, Rizal, Aji Erlangga M dan Ahim Abdurahim. 2009. Akuntansi Perbankan Syariah ' Teori dan Praktik Kontemporer'. Salemba Empat. Jakarta.

Yuda, I Made P dan Wahyu Meiranto. 2010. Pengaruh Faktor Internal
Bank terhadap Jumlah Kredit yang Disalurkan (Studi Empiris pada Bank yang Terdaftar di Bursa Efek Indonesia). Jurnal Akuntansi dan Auditing 7 (1): 94-110.

Yulhasnita. 2011. Pengaruh CAR, ROA, ROE, BOPO, dan LDR terhadap Penyaluran Kredit pada Perusahaan Perbankan yang Terdaftar di Bursa Efek Indonesia (BEI). Universitas Riau. 